\title{
Advances in the research of basic study and clinical application of adipose-derived mesenchymal stem cells
}

\author{
Shengjun Cao, Lingfeng Wang, Te Ba, Zhidong Rong, Guolin Hu, Biao Zhou, Quan Li \\ Department of Burns, The Third Affiliated Hospital of Inner Mongolia Medical University, Baotou, China
}

Received: January 24, 2018

DOI: $10.14725 /$ dcc.v5n1p36
Accepted: March 7, $2018 \quad$ Online Published: March 10, 2018

URL: http://dx.doi.org/10.14725/dcc.v5n1p36

\begin{abstract}
Since the discovery of adipose-derived mesenchymal stem cell (ADSC) in more than ten years, a great progress has been made from its basic research to clinical application. Compared with bone marrow mesenchymal stem cells, ADSC is more abundant in reserve, easier to obtain with fewer injuries and less complications. These cells have multiple differentiation potential and can differentiate into adipocytes, chondrocytes and osteoblasts with the influence of different inducing factors. Early studies of ADSC mainly focused on the ability of multi-directional differentiation, especially on the regeneration of bone defects and cartilage tissue. At present, the researches mainly focus on immunoregulation and paracrine function of ADSC. Although ADSC has made a great progress in clinical application, the cell preparation, use pattern, and mechanisms in clinical treatment are not clear. This paper elaborates on these issues.
\end{abstract}

Key Words: Stem cells, Adipose-derived stem cell, Basic research, Clinical application

In 2001, Zuk et al. ${ }^{[1]}$ firstly cultured a type of mesenchymal stem cell (MSC) in adipose tissue suspension from liposuction. It has the potential of multi-differentiation. Under different induction factors, it can be differentiated to adipocytes, chondrocytes, osteoblasts and so on, which is called adipose-derived mesenchymal stem cell (ADSC). Since then, it has gradually become a hot research topic of scientists all over the world. The clinical application of ADSC is similar to that of bone marrow mesenchymal stem cell (BMSC), but ADSC is richer in the body. And the acquisition is simple, the injury is small, the complication is less. The initial research on the application of ADSC was mainly focused on its multidirectional differentiation potential, and some progress was made in clinical trials. But the differentiation potential is not the only factor that affects the clinical effect when studying the mechanism of action. The immune regulation and paracrine function of ADSC also play important roles. This result has made a great change in the direction of research on the therapeutic effect of ADSC. Although there is a great progress on the clinical application of ADSC, there are still many problems to be studied about the mechanism of its clinical effect. This paper describes the acquisition, use, basic and clinical application of ADSC, strategies for improving its efficacy and cell-free therapy etc.

\section{ADSC acquisition and surface markers}

Vascular stromal cell (SVF) in adipose tissue is obtained by collagenase or trypsin digestion, filtration and centrifugation of adipose tissue granules, which is cell mass with

\footnotetext{
*Correspondence: Lingfeng Wang; E-mail: wlf7413@vip.sina.com; Address: Department of Burns, The Third Affiliated Hospital of Inner Mongolia Medical University, Baotou, China.
} 
stem cell characteristics, including endothelial progenitor cells, immune cells, MSC and blood derived cells and so on. ADSC can be obtained through adherent culture and purification of SVF in adipose tissue. Put SVF into the cell culture dish. During the process of culture, the non-adherent cells such as endothelial progenitor cells and hematopoietic cells can be removed through changing of culture medium for several times. Adherent non-proliferative cells will be replaced by ADSC which can self-proliferate and labeled. ${ }^{[2-4]}$ Zuk et al. ${ }^{[1]}$ firstly obtained ADSC by adherent culture and purification. The amount of cells obtained by this method is large, but it is time-consuming and costly. At present, the methods of obtaining ADSC include direct centrifugation, adsorption column, immunomagnetic bead sorting, density gradient centrifugation and so on. ${ }^{[5]}$ These methods do not need to amplify the cells and ADSC can be obtained within a few hours, which significantly shorten the extraction time, but the number of cells obtained is small. Both ADSC and SVF in adipose tissue have stem cell properties, but there are differences. Because SVF also contains cells such as endothelial progenitor cells, it has more advantages than ADSC in wound treatment, but the number of extracted cells is limited. The ADSC obtained by purification of SVF from adipose tissue can proliferate in a large number during a long period of time, so the allogeneic cell bank can be established by this method to provide allogeneic stem cells for clinical stem cell therapy. The establishment of allogeneic ADSC cell bank can guarantee the homology of stem cells in clinical treatment, obviate the culture of autologous stem cells and shorten the course of disease. The effects of polymorphism among ADSC donors and different isolation and culture methods used by different study groups are excluded in the study. ${ }^{[6-8]}$

ADSC can be identified by cell phenotypic characteristics, and the dynamic expression of CD34, CD105 is very important to the identification of ADSC. The International Association for Cell Therapy points out that cultured MSC all express cell surface markers $\mathrm{CD} 34^{-}, \mathrm{CD} 45^{-}, \mathrm{CD}^{+} 3^{+}$, $\mathrm{CD}^{+}{ }^{+}, \mathrm{CD}_{105^{+}}$and major histocompatibility complex II molecule. ${ }^{[9]}$ However, the fresh ADSC isolated from adipose is not consistent with the previous situation. It expresses high CD34 and low CD105. ${ }^{[2,3]}$ ADSC can be identified through the study of its phenotypic characteristics, which is helpful for clinical study.

\section{Usage mode}

ADSC can play a therapeutic role by arteriovenous injection, injecting directly into human organs or tissues, and all of them depend on the chemotaxis of ADSC to the diseased tissues. ${ }^{[10]}$ Chemokine receptors are expressed on the surface of MSC cells including ADSC, which allows them to migrate to damaged tissues along the concentration gradient of chemokines secreted by inflammatory tissues. For example, Cho et al. ${ }^{[11]}$ found that human ADSC could migrate to the nasal lesion tissue of allergic rhinitis model in mice. But it is not clear how many cells can migrate to the pathological tissue after ADSC is given throughout the body. Another research showed that some cells assembled at the tissue of lung, liver, heart and brain after intravenous injection of ADSC to patients. In patients who increased ADSC injection to improve efficacy, the cells assembled and led to tissue embolism of heart, liver and brain etc., and with the risk of obstruction of blood flow. ${ }^{[10]}$ As an alternative to systemic use, local application of ADSC to diseased tissue can improve the efficiency of implantation. ${ }^{[12]}$ It avoids the dependence of chemokines secreted by diseased tissues and the risk of systemic use. At present, some diseases have been successfully treated by local application of ADSC, such as myocardial necrosis after myocardial infarction, bone defect and local wound. ${ }^{[10,13]}$ But this method is to bring cells into the microenvironment of the allogeneic body, which can cause inflammatory reaction, and compete with target tissue cells to use oxygen and nutrients. It is also invasive. ${ }^{[14]}$ Therefore, before clinical application of ADSC, careful consideration should be given to how to use it to achieve the best therapeutic effect.

\section{Basic and clinical application}

The basic and clinical application of ADSC is mainly based on its multidirectional differentiation potential of lipid, osteogenic and chondrogenic, and paracrine $\&$ immune regulation.

\subsection{Application of adipogenic differentiation}

ADSC can differentiate into adipose cell and form adipose tissue, which can be used as a filler for breast reconstruction, breast augmentation, facial rejuvenation and hypertrophic scar treatment. The condition for long-term survival after adipose transplantation is that the transplanted adipose tissue can supply new blood. Under normal conditions, some of the transplanted adipose tissue will be absorbed within a few months after adipose transplantation, so the current research is focusing on how to improve the survival rate of transplanted adipose. Studies have shown that the culture and transformation of adipose cells before back injection suction can increase their survival rate, ${ }^{[17]}$ while, it also increases the time and cost of treatment. ${ }^{[18]}$ Another approach is autogenous adipose transplantation. ${ }^{[19]}$ Routine extraction of adipose tissue, one half is used to prepare SVF, and the extracted SVF is added to the other half of the unprocessed adipose tissue to increase the injection quantity of ADSC, so that the transplanted adipose can survive for a long time. ${ }^{[20]}$ The advantage of this method is that it can complete the operation at one time without increasing the number of operations, shorten the treatment time and reduce 
the cost of the treatment, in which the process of preparing SVF takes about 90 minutes. At present, there is a cell processing device called Celution system, which can complete the above process automatically.

\subsection{Application of osteogenic differentiation}

The human body has the ability to self repair fractures and small bone defects. However, if the bone defect is serious or the fracture is delayed due to biomechanical factors that are not conducive to healing, the effect of adjuvant treatment with ADSC is better. The first case of bone tissue defect treatment with ADSC was to use SVF combined bone and fibrin glue transplantation to treat cranial fornix defect after craniocerebral injury. ${ }^{[21]}$ There are many basic studies on osteogenic differentiation of ADSC in literatures and reports, but the method of applying ADSC in the study is different from that in clinical application of tissue engineering bone. Tissue engineering bone commonly used in clinical practice is a relatively large three-dimensional structure. However, the bone tissues differentiated from ADSC are small particles, which are not enough to repair a large area of bone defect. Therefore, the clinical application of SVF and ADSC in differentiation osteogenesis must be combined with bone guiding substances (such as calcium phosphate or bone morphogenetic protein). It was also reported that ADSC combined with ectopic bone to repair maxilla, craniofacial reconstruction of cranium and its combination with hyaluronic acid stent in the treatment of osteonecrosis of femoral head. ${ }^{[22,23]}$

\subsection{Application of chondrogenic differentiation}

Osteoarthritis is a degenerative disease of articular cartilage caused by many causes, which is characterized by joint pain and often leads to the loss of joint function. Due to the lack of treatment, joint replacement surgery is needed to solve the joint dysfunction. It is lack of effective clinical treatment. Many studies have confirmed that ADSC can differentiate into cartilage, and can be proved by oil red $\mathrm{O}$ or toluidine blue staining. But the vitro observation showed that its ability to differentiate into cartilage was very weak. ${ }^{[24,25]}$ In the experiment of safety and adverse reaction of ADSC differentiation into cartilage for clinical treatment, it was observed that both clinical symptoms and limited function of patients were improved, and hyaline cartilage volume was increased under arthroscopy. ${ }^{[24]}$ Other studies have shown that BMSC has a stronger ability of chondrogenic differentiation than ADSC. Filardo et al. ${ }^{[26]}$ reviewed 90 research papers on the clinical application of ADSC chondrogenic differentiation, including 72 preclinical studies and 18 clinical experiments. Only 2 clinical experiments recommended ADSC. It can be seen that ADSC has the ability to regenerate articular cartilage, but its clinical application effect is not satisfactory.

\subsection{Application in wound healing}

In the study of ADSC promoting wound healing, ADSC promotes wound healing through its multidirectional differentiation potential and paracrine effect. ${ }^{[27-29]}$ ADSC has the ability of self-renewal and multi-differentiation. It can proliferate and differentiate into cells which are needed for wound repair, such as $\mathrm{KC}$, hair follicle cells, sebaceous gland cells, sweat gland cells etc. ${ }^{[29]}$ Other researchers used ADSC to repair Crohn's disease intestinal ulcer, and the effect was good. The transplanted ADSC worked on local cells by secreting cytokines to promote tissue vessel regeneration and reduce local tissue inflammation. ${ }^{[30,31]}$ It has expanded the application of ADSC in the field of clinical repair. Comparative study of using ADSC combining with fibrin glue and fibrin glue alone in the treatment of burn wounds in rats, the combination of ADSC was with higher curative ratio, which promoted the wound healing, increased the secretion of vascular endothelial growth factor and alleviated the inflammatory reaction. ${ }^{[32,33]}$ In recent years, there were also attempts to use ADSC in the treatment of advanced cancer radiation injury and to reduce the complications after limited operation, which has achieved a certain effect. ${ }^{[34,35]}$

\subsection{Treatment of heart disease}

The application of ADSC in the treatment of heart disease is mainly about the regeneration of myocardial cells after myocardial infarction and the recovery of cardiac function. The mechanism is not clear, but it is generally believed to be realized through its paracrine effect. ${ }^{[36,37]} 72$ hours after intramyocardial injection of BMSC, cardiomyocyte regeneration was observed and ventricular function was improved. ${ }^{[38]}$ The time is much shorter than that required for ADSC to differentiate into cardiomyocytes, suggesting that the therapy does not play a therapeutic role through the differentiation of ADSC. In an experiment to compare the effects of human ADSC and BMSC on myocardial infarction model of rats, the rats were given BMSC, ADSC and physiological saline respectively through intramyocardial injection. The results showed that both BMSC and ADSC could prevent left ventricular dilatation. But only the left ventricular function of the rats treated with ADSC improved after 4 weeks of treatment. ${ }^{[39]}$ In the phase III clinical trial of intracoronary infusion of ADSC in the treatment of acute myocardial infarction, the cardiac function of patients injected with ADSC was improved and no serious adverse events occurred. ${ }^{[40]}$ The application of stem cells in the treatment of heart disease is still in its infancy, and its mechanism, methods, safety \& efficacy, and transplant rejection need to be scientifically demonstrated by a large number of in-depth multicenter randomized controlled trials. 


\subsection{Treatment of nervous system diseases}

ADSC plays a therapeutic role in nervous system diseases through the paracrine effect and multiple differentiations potential. Endogenous neural stem cells and Schwann cells play important roles in nerve development and repair after injury and nerve degeneration, but the acquisition of these cells is difficult. Studies have shown that ADSC can be used to improve functional recovery after nerve injury. ${ }^{[41]}$ Mantovani et al. ${ }^{[42]}$ found that ADSC could differentiate into autologous Schwann lineage cells with functional and secretive growth factors, which has broken limitation of low growth rate of Schwann cells. In the process of motor nerve repair, these cells can differentiate into nerve fiber sheath and promote the recovery of motor function. ADSC can also be induced to differentiate into exogenous neural stem cells in vitro and repair nerve injury, and the effect is better. ${ }^{[43]}$ In the study of the effect of immune signal on cellular behavior, some researchers have determined that inflammatory cytokines have an effect on nerve regeneration, so ADSC, which secretes anti-inflammatory cytokines, has a neurotrophic effect. ${ }^{[4]}$ An evaluation of ADSC auxiliary nerve regeneration in mice has shown that intravenous or marginal cerebral injection of ADSC improves memory impairment in mice. In addition to the migration and differentiation of ADSC into neurons, the mechanisms mainly include the paracrine effects of cytokines or neurotrophic factors secreted by ADSC. ${ }^{[45]}$

In the treatment of spinal cord injury, the effect of hormone therapy is not ideal. So stem cell therapy has been developed recently. An intravenous injection of oligodendrocyte precursor cell derived from rat ADSC to spinal cord injury rat models showed that the motor function of the rats was significantly improved. ${ }^{[45]}$ Another study showed that, regardless of the source of neural stem cells (for example, through ADSC differentiation, BMSC differentiation, subependymal tissue centrifugation, etc.), less than $1 \%$ of neural stem cells actually survived in focus of infection and differentiated into oligodendrocytes. This suggests that the main mechanism of ADSC in the treatment of spinal cord injury is paracrine effect. ${ }^{[46]}$

\subsection{Treatment of tumor}

Some cytokines released by tumor cells can raise ADSC into tumor tissues. ${ }^{[4]}$ Based on this characteristic, ADSC can be genetically modified to carry specific genes into the target tissue for expression, so as to play a therapeutic role. This method has become a research hotspot, for example, combined use of stem cells and precursor drugs for cancer treatment. Gene modification enables ADSC to express an enzyme in tumor tissue. The enzyme can be applied into nontoxic precursor drugs in tumor tissues, convert to a therapeutic cytotoxic drug and kill adjacent tumor cells. ${ }^{[48]}$ Researchers have also transfected the gene, ex- pressed yeast cytosine deaminase-uracil phosphate ribose, transformed ADSC of the enzyme, and combined tumor treatment precursor drug 5-flurocytosine. Glioma in rats was successfully cured. ${ }^{[4]}$ The tumor lysate virus has the characteristic of tumor phagocytosis. Some researchers injected the gene-modified ADSC expressing oncolytic virus into the mouse model of malignant glioma. Finally, the survival time of mice was prolonged, and the effect of multiple injections was better. ${ }^{[50]}$ There is a stem cell mediated suicide gene therapy. Some studies treated retrovirus as a carrier, transfected human ADSC into TNF-related apoptosisinducing ligand and then transplanted it into cervical cancer mice to reduce tumor. This cell can also kill cells of breast cancer, cervical cancer, colon cancer, pancreatic cancer and so on in vitro. ${ }^{[51,52]}$

\subsection{Other application}

In addition to the above mentioned, ADSC is also used in some other disease treatment and research, which is also with certain therapeutic effect. For example, injection of allogeneic rat ADSC into emphysema rat model can effectively inhibit alveolar cell apoptosis, indicating that it has a potential therapeutic effect on emphysema. ${ }^{[53]}$ Some researchers have differentiated ADSC into pancreatic islet cells and injected it into diabetic rat model, which improved sensitivity of rats to insulin and had a therapeutic effect on type 1 diabetes. ${ }^{[54]}$

\section{Strategies for improving the efficacy of ADSC}

\subsection{Improve homing ability}

The process of autologous or allogeneic ADSC migration to target tissue and colonization under the action of many factors is called homing of ADSC. The number of therapeutic ADSC homing to the diseased tissue determines its efficacy. At present, the homing mechanism of ADSC is not clear, but some methods can improve its homing ability. ${ }^{[55]}$ Fresh isolated MSC has stronger homing ability than MSC cultured in subsequent culture. ${ }^{[56]}$ This is due to the aging or oxidative damage on the surface of MSC during culture, which reduces its cell surface receptors such as the chemokine receptor 4 necessary for homing. In order to counteract the effect of culture on cells, cytokines can be used to induce the cells. ${ }^{[57]}$ It can also induce the high expression of chemokine receptor and improve the homing ability of ADSC by virus transfection. ${ }^{[58]}$ In addition, some culture medium can improve the homing ability of MSC. The researchers compared the results of MSC amplification in vitro by using different cell mediums and found that the homing ability of MSC cultured in low glucose DMEM medium, GlutaMAX medium and low density medium was 
stronger. ${ }^{[59]}$

\subsection{Pretreatment}

Cells can be pretreated or modified by physical, chemical, genetic or molecular stimulation methods before treatment with ADSC to improve cell survival rate, increase paracrine function, enhance differentiation potential, thus improving curative effects. At the molecular level, ADSC can be modified by virus as a vector. ADSC modified by gene can overexpress various cytokines and enhance paracrine function. ${ }^{[60,61]}$ Some researchers transfected pancreasduodenum homologous gene box 1 into ADSC by lentivirus vector to promote the expression of insulin. The transfected ADSC has the ability to treat diabetic mice. ${ }^{[62]}$ However, genetic modification using lentivirus or retrovirus as a vector may lead to insertion mutation, and may have the risk to cause oncogene activation and epigenetic changes. ${ }^{[63]}$ This can be avoided by transfection using adenovirus as a vector because the transfected genes cannot be integrated into the host genome. Some researchers transfected ADSC and expressed bone morphogenetic protein-2 via adenovirus vector, and implanted the transfected ADSC into the scaffold of posterior limb bone defect of immunodeficient mice, which increased the formation rate of bone tissue finally. ${ }^{[64]}$ In addition, there is preprocessing through gene knockout. For example, sildenafil or short hairpin RNA was used for preprocessing to inhibit ADSC to express phosphodiesterase 5 , which improved the therapeutic effect of intramyocardial injection of ADSC after myocardial infarction in mice. ${ }^{[65]}$

\section{Cell-free therapy}

The experiment proves that the culture supernatant treatment with ADSC can obtain the same effect as that with ASCS. ${ }^{[66]}$ This may also suggest that paracrine action may be the main mechanism for the therapeutic effect of ADSC. ADSC will release a variety of bubble bag to outside of

\section{References}

[1] Zuk PA, Zhu M, Mizuno H, et al. Mutilineage cells from human adipose tissue: implications for cell-based therapies. Tissue Eng. 2001; 7(2): 211-228. PMid: 11304456. https://doi.org/10. 1089/107632701300062859

[2] Bourin P, Bunnell BA, Casteilla L, et al. Stromal cells from the adipose tissue-derived stromal vascular fraction and culture expanded adipose tissue-derived stromal/stem cells: a joint statement of the International Federation for Adipose Therapeutics and Science (IFATS) and the International Society for Cellular Therapy (ISCT). Cytotherapy. 2013; 15(6): 641-648. PMid: 23570660. https://doi.org/10.1016/j.jcyt.2013.02.006

[3] Feisst V, Brooks AE, Chen CJ, et al. Characterization of mesenchymal progenitor cell populations directly derived from human der- cell from intracellular interval, in which exocrine is with the strongest biological effects. These plasma membrane microbubbles, which have a diameter of 30-100 nm, contain biological information such as protein, mRNA and tiny RNA derived from the original cells, ${ }^{[67]}$ which can be used as a carrier of intercellular substance and information exchange. ${ }^{[68]}$ A large number of animal experiments show that the exocrine secreted by MSC has a therapeutic effect on some diseases such as cardiovascular disease, acute renal injury, liver injury, lung injury, refractory wound and so on. ${ }^{69]}$ Arslan et al. ${ }^{[70]}$ found that intravenous injection of extracellular vesicles reduced myocardial infarction size by $45 \%$, improved cardiac function and alleviated inflammation in mice. Compared with the whole stem cell therapy, the exocrine has no risk of immune response and tumorigenicity, and its function will not lose in long-term storage, and can be prepared for storage as a finished product. ${ }^{[69]}$ MSC has the ability to promote the growth of primary tumor, and its secreted exocrine may have the same effect. Therefore, the safety of cell-free therapy using exocrine secreted by MSC also needs to be fully studied.

\section{Summary and Prospect}

Significant progress has been made in the clinical study of ADSC. The therapeutic potential of ADSC rapidly expanded from the beginning of the study on the mechanism of differentiation and proliferation to the study of paracrine effect. However, in previous studies, different methods of cell isolation and preparation, patient and disease heterogeneity have resulted in significant differences in the clinical trial results of ADSC. With the development of the research and the combination of basic research and clinical trials, it is believed that ADSC therapy will play an important role in clinical practice in the near future.

\section{Conflicts of Interest Disclosure}

The authors have no conflicts of interest related to this article.

mis. Stem Cells Dev. 2014; 23(6): 631-642. PMid: 24325341. https://doi.org/10.1089/scd.2013.0207

[4] Braun J, Kurtz A, Barutcu N, et al. Concerted regulation of CD34 and CD105 accompanies mesenchymal stromal cell derivation from human adventitial stromal cell. Stem Cells Dev. 2013; 22(5): 815827. PMid: 23072708. https://doi.org/10.1089/scd.2012. 0263

[5] Liu Q, Wang LP, Chen F, et al. Research Progress of Isolation and Purification of Adipose Stem Cells. Chinese Journal of Comparative Medicine. 2015; 25(7): 69-73. PMid: 25563316. https: //doi.org/10.4103/0366-6999.147815

[6] Mendicino M, Bailey AM, Wonnacott K, et al. MSC-based product characterization for clinical trials: an FDA perspective. Cell Stem Cell. 2014; 14(2): 141-145. PMid: 24506881. https://doi.org/ $10.1016 / j$.stem. 2014.01 .013 
[7] Koellensperger E, Bollinger N, Dexheimer V, et al. Choosing the right type of serum for different applications of human adipose tissue-derived stem cells: influence on proliferation and differentiation abilities. Cytotherapy. 2014; 16(6): 789-799. PMid: 24642018. https://doi.org/10.1016/j.jcyt.2014.01.007

[8] Roldan M, Macias-Gonzalez M, Garcia R, et al. Obesity shortcircuits stemness gene network in human adipose multipotent stem cells. FASEB J. 2011; 25(12): 4111-4126. PMid: 21846837. https://doi.org/10.1096/fj.10-171439

[9] Dominici M, Le Blanc K, Mueller I, et al. Minimal criteria for defining multipotent mesenchymal stromal cells. The International Society for Cellular Therapy position statement. Cytotherapy. 2006; 8(4): 315-317. PMid: 16923606. https://doi.org/10.1080/ 14653240600855905

[10] Atala A, Lanza R, Thomson JA, et al. Principles of regenerative medicine. $2^{\text {nd }}$ ed. San Diego: Academic Press; 2011. 365-381 p.

[11] Cho KS, Park HK, Park HY, et al. IFATS collection: immunomodulatory effects of adipose tissue-derived stem cells in an allergic rhinitis mouse model. Stem Cells. 2009; 27(1): 259-265. PMid: 18832595. https://doi.org/10.1634/stemcells. 2008-0283

[12] Rigol M, Solanes N, Farre J, et al. Effects of adipose tissue-derived stem cell therapy after myocardial infarction: impact of the route of administration. J Card Fail. 2010; 16(4): 357-366. PMid: 20350704. https://doi.org/10.1016/j.cardfail.2009.12.006

[13] Huang WF, Jiang P. Research Progress and Application Prospect of Adipose Stem Cells in Wound Healing. Chinese Journal of Experimental Surgery. 2015; 32(1): 208-209. PMid: 25565868.

[14] Muschler GF, Nakamoto C, Griffith LG. Engineering principles of clinical cell-based tissue engineering. J Bone Joint Sug Am. 2004; 86(7): 1541-1558. https://doi.org/10.2106/ 00004623-200407000-00029

[15] Han CJ, Yang XQ, Zhang CS. Immunological Properties of Adipose Stem Cells. Chinese Journal of Tissue Engineering Research and Clinical Rehabilitation. 2010; 14(27): 5095-5098.

[16] Li P, Feng Y. Advances in Research on Adipose Stem cells and Tissue Regeneration. Chinese Medical Report. 2015; 12(7): 37-41.

[17] Sajjadian A, Tandav MK. Treating facial soft tissue deficiency: fat grafting and adipose-derived stem cell tissue engineering. Aesthet Surg J. 2007; 27(1): 100-104. PMid: 19341636. https://doi . org/10.1016/j.asj.2006.12.001

[18] Zhu XZ, Gao W, Cui CY, et al. Application of Autologous Adipose Stem Cell Transplantation in Facial Rejuvenation. International Medicine and Health Guidance News. 2016; 22(1): 66-68.

[19] Matsumoto D, Sato K, Gonda K, et al. Cell-assisted lipotransfer: supportive use of human adipose-derived cells for soft tissue augmentation with lipoinjection. Tissue Eng. 2006; 12(12): 3375-3382. PMid: 17518674. https://doi.org/10.1089/ten.2006.12. 3375

[20] Yoshimura K, Sato K, Aoi N, et al. Cell-assisted lipotransfer for facial lipoatrophy: efficacy of clinical use of adipose-derived stem cells. Dermatol Surg. 2008; 34(9): 1178-1185. https : //doi .org/ 10.1097/00042728-200809000-00003

[21] Lendeckel S, Jodicke A, Christophis P, et al. Autologous stem cells (adipose) and fibrin glue used to treat widespread traumatic calvarial defects: casc roport. J Craniomaxillofac Surg. 2004; 32(6): 370-373. PMid: 15555520. https://doi.org/10.1016/j.jcms. 2004. 06.002

[22] Mesimaki K, Lindroos B, Tornwall J, et al. Novel maxillarv reconstmction with ectopic bone fomation by GMP adipose stem cells. Int J Oral Maxillofac Sug. 2009; 38(3): 201-209. PMid: 19168327. https://doi.org/10.1016/j.ijom.2009.01.001

[23] Pak J. Autologous adipose tissue-derived stem cells induce persistent bone-like tissue in osteonecrotic femoral heads. Pain Physician. 2012; 15(1): 75-85. PMid: 22270740.

[24] Jo CH, Lee YG, Shin WH, et al. Intra-articular injection of mesenchymal stem cells for the treatment of osteoarthritis of the knee: a proof-of-concept clinical trial. Stem Cells. 2014; 32(5): 1254-1266. PMid: 24449146. https ://doi.org/10.1002/stem. 1634
[25] An RZ, Zhao JY, Wang ZJ. Comparison of Chondrogenic Capacity between Adipose Stem Cell and Bone Marrow Mesenchymal Stem Cell. Chinese Journal of Research on Tissue Engineering. 2013; 17(32): 5793-5798.

[26] Filardo G, Madry H, Jelic M, et al. Mesenchymal stem cells for the treatment of cartilage lesions: from preclinical findings to clinical application in orthopaedics. Knee Surg Sports Traumatol Arthrosc. 2013; 21(8): 1717-1729. PMid: 23306713. https://doi.org/ 10.1007/s00167-012-2329-3

[27] Kim WS, Park BS, Sung JH. The wound-healing and antioxidant effects of adipose-derived stem cells. Expert Opin Biol Ther. 2009; 9(7): 879-887. PMid: 19522555. https://doi.org/10.1517/ 14712590903039684

[28] Hocking AM, Gibran NS. Mesenchymal stem cells: paracrine signaling and differentiation during cutaneous wound repair. Exp Cell Res. 2010; 316(14): 2213-2219. PMid: 20471978. https://doi. org/10.1016/j.yexcr.2010.05.009

[29] Yang YQ, Ren J, Sun JM. Research Progress on Differentiation of Adipose Stem Cells to Epithelial Cells. Chinese Journal of Medical Aesthetics and Beauty. 2015; 21(6): 382-384.

[30] Xie MH, He XS, Zhu JL, et al. Experimental Study on the Treatment of Crohn's Disease with Adipose-derived Mesenchymal Stem Cells. Chinese Journal of Gastrointestinal Surgery. 2015; 18(1): 5864. PMid: 25656034.

[31] Garcia-Olmo D, Herreros D, Pascual I, et al. Expanded adiposederived stem cells for the treatment of complex perianal fistula: a phase II clinical trial. Dis Colon Rectum. 2009; 52(1): 79-86. PMid: 19273960. https://doi.org/10.1007/DCR. Ob013e3181973487

[32] Atalay S, Coruh A, Deniz K. Stromal vascular fraction improves deep partial thickness bum wound healing. Burns. 2014; 40(7): 1375-1383. PMid: 24572074. https://doi.org/10.1016/j. burns. 2014.01.023

[33] Lalu MM, McIntyre L, Pugliese C, et al. Safety of cell therapy with mesenchymal stromal cells (safecell): a systematic review and meta-analysis of clinical trials. PLoS One. 2012; 7(10): e47559. PMid: 23133515. https ://doi.org/10.1371/journal.pone. 0047559

[34] Irani Y, Casanova D, Amar E. Autologous fat grafting in radiated tissue prior to breast prosthetic reconstruction: is the technique reliable? Ann Chir Plast Esthet. 2012; 57(1): 59-66. PMid: 21145645. https://doi.org/10.1016/j.anplas.2010.11.002

[35] Salgarello M, Visconti G, Farallo E. Autologous fat graft in radiated tissue prior to alloplastic reconstruction of the breast: report of two cases. Aesthetic Plast Surg. 2010; 34(1): 5-10. PMid: 19471898. https ://doi .org/10.1007/s00266-009-9367-3

[36] Ma T. Mesenchymal stem cells: from bench to bedside. World J Stem Cells. 2010; 2(2): 13-17. PMid: 21607111. https://doi. org/10.4252/wjsc.v2.i2.13

[37] Xie ST, Fan L, Yang LL, et al. Protective Effect of Adipose Mesenchymal Stem Cells on Early Myocardial Injury of Severely Burned Rats. Chinese Journal of Injury and Repair: Electronic. 2015; 10(4): 284-289.

[38] Gnecchi M, Zhang Z, Ni A, et al. Pamcrine mechanisms in adult stem cell signaling and therapy. Circ Res. 2008; 103(11): 1204-1219. PMid: 19028920. https://doi.org/10.1161/ CIRCRESAHA . 108.176826

[39] Rasmussen JG, Frøbert O, Holst-Hansen C, et al. Comparison of human adipose-derived stem cells and bone marrow-derived stem cells in a myocardial infarction model. Cell Transplantation. 2014; 23(2): 195-206. PMid: 23211469. https://doi.org/10.3727/ $096368912 \times 659871$

[40] Houtgraaf JH, den Dekker WK, van Dalen BM, et al. First experience in humans using adipose tissue-derived regenerative cells in the treatment of patients with ST-segment elevation myocardial infarction. Journal of the American College of Cardiology. 2012; 59(5): 539-540. PMid: 22281257. https://doi.org/10.1016/ j.jacc. 2011.09 .065 
[41] Yang L, Fang JS, Wang W, et al. Transplantation of Schwann cells differentiated from adipose-derived stem cells modifies reactive gliosis after contusion brain injury in rats. Journal of International Medical Research. 2011; 39(4): 1344-1357. PMid: 21986135. https://doi.org/10.1177/147323001103900421

[42] Mantovani C, Terenghi G, Shawcross SG. Isolation of adult stem cells and their differentiation to Schwann cells. Methods Mol Biol. 2012; 916: 47-57. PMid: 22914932. https://doi.org/10. 1007/978-1-61779-980-8_5

[43] Kang SK, Shin MJ, Jung JS, et al. Autologous adipose tissue-derived stromal cells for treatment of spinal cord injury. Stem Cells \& Development. 2006; 15(4): 583. PMid: 16978061. https://doi.org/ 10.1089/scd.2006.15.583

[44] Carpentier PA, Palmer TD. Immune Influence on Adult Neural Stem Cell Regulation and Function. Neuron. 2009; 64(1): 7992. PMid: 19840551. https://doi.org/10.1016/j.neuron. 2009.08.038

[45] Chang KA, Kim HJ, Joo Y, et al. The therapeutic effects of human adipose-derived stem cells in Alzheimer's disease mouse models. Neurodegenerative Diseases. 2013; 13(2-3): 99-102. PMid: 24157626. https://doi.org/10.1159/000355261

[46] Zhang HT, Cheng HY, Cai YQ, et al. Comparison of adult neurospheres derived from different origins for treatment of rat spinal cord injury. Neuroscience Letters. 2009; 458(3): 116121. PMid: 19394407. https://doi.org/10.1016/j.neulet. 2009.04.045

[47] Lee DH, Ahn Y, Kim Su, et al. Targeting rat brainstem glioma using human neural stem cells and human mesenchymal stem cells. Clin Cancer Res. 2009; 15(15): 4925-4934. PMid: 19638465. https ://doi.org/10.1158/1078-0432.CCR-08-3076

[48] Stuckey DW, Shah K. Stem cell-based therapies for cancer treatment: separating hope from hype. Nature Reviews Cancer. 2014; 14(10): 683-91. PMid: 25176333. https://doi.org/10.1038/ nrc3798

[49] Gleizes C, Constantinescu A, Abbas M, et al. Complete regression of glioblastoma by mesenchymal stem cells mediated prodrug gene therapy simulating clinical therapeutic scenario. International Journal of Cancer. 2014; 134(6): 1458-1465. PMid: 24038033. https://doi.org/10.1002/ijc. 28455

[50] Josiah DT, Zhu D, Dreher F, et al. Adipose-derived stem cells as therapeutic delivery vehicles of an oncolytic virus for glioblastoma. Molecular Therapy. 2010; 18(2): 377-85. PMid: 19904233. https://doi.org/10.1038/mt.2009.265

[51] Grisendi G, Bussolari R, Cafarelli L, et al. Adipose-derived mesenchymal stem cells as stable source of tumor necrosis factor-related apoptosis-inducing ligand delivery for cancer therapy. Cancer Res. 2010; 70(9): 3718-3729. PMid: 20388793. https://doi.org/ 10.1158/0008-5472. CAN-09-1865

[52] Tian JQ, Wang ZP, Fu SJ, et al. Inhibitory Effect of Tumor Necrosis Factor-related Apoptosis-inducing Ligand Transfection on Bladder Cancer Cells. Chinese Journal of Experimental Surgery. 2016; 23(5): 568-570.

[53] Shigemura N, Okumura M, Mizuno S, et al. Autologous transplantation of adipose tissue-derived stromal cells ameliorates pulmonary emphysema. American Journal of Transplantation. 2010; 6(11): 2592-2600. PMid: 17049053. https://doi.org/10.1111/j. 1600-6143.2006.01522.x

[54] Karaoz E, Okcu A, Unal ZS, et al. Adipose tissue-derived mesenchymal stromal cells efficiently differentiate into insulin-producing cells in pancreatic islet microenvironment both in vitro and in vivo. Cytotherapy. 2013; 15(5): 557-570. PMid: 23388582. https://doi. org $/ 10.1016 / j \cdot j$ cyt . 2013.01.005

[55] Tholpady SS, Ogle RC, Katz AJ. Adipose stem cells and solid organ transplantation. Current Opinion in Organ Transplantation. 2009; 14(1): 51-5. PMid: 19337147. https://doi.org/10. 1097/MOT . Ob013e328320d2cf
[56] Rombouts WJC, Ploemacher RE. Primary murine MSC show highly efficient homing to the bone marrow but lose homing ability following culture. Leukemia. 2003; 17(1): 160-170. PMid: 12529674. https://doi.org/10.1038/sj.leu.2402763

[57] Shi M, Li J, Liao L, et al. Regulation of CXCR4 expression in human mesenchymal stem cells by cytokine treatment: role in homing efficiency in NOD/SCID mice. Haematologica. 2007; 92(7): 897. PMid: 17606439. https://doi.org/10.3324/haematol. 10669

[58] Zhou B, Han ZC, Poon MC, et al. Mesenchymal stem/stromal cells (MSC) transfected with stromal derived factor 1 (SDF-1) for therapeutic neovascularization: enhancement of cell recruitment and entrapment. Medical Hypotheses. 2007; 68(6): 1268-1271. PMid: 17197116. https://doi.org/10.1016/j.mehy.2006.09.066

[59] Sotiropoulou PA, Perez SA, Salagianni M, et al. Characterization of the Optimal Culture Conditions for Clinical Scale Production of Human Mesenchymal Stem Cells. Stem Cells. 2010; 24(2): 462-471. PMid: 16109759. https://doi.org/10.1634/ stemcells.2004-0331

[60] Gauglitz GG, Jeschke MG. Combined Gene and Stem Cell Therapy for Cutaneous Wound Healing. Molecular Pharmaceutics. 2011; 8(5): 1471-9. PMid: 21657247. https://doi.org/10.1021/ mp2001457

[61] Branski LK, Gauglitz GG, Herndon DN, et al. A review of gene and stem cell therapy in cutaneous wound healing. Burns Journal of the International Society for Burn Injuries. 2009; 35(2): 171-180. PMid: 18603379. https://doi.org/10.1016/j.burns.2008. 03.009

[62] Lin G, Wang G, Liu G, et al. Treatment of Type 1 Diabetes With Adipose Tissue-Derived Stem Cells Expressing Pancreatic Duodenal Homeobox 1. Stem Cells \& Development. 2009; 18(10): 1399. PMid: 19245309. https://doi.org/10.1089/scd.2009.0010

[63] Herberts CA, Kwa MS, Hermsen HP. Risk factors in the development of stem cell therapy. Journal of Translational Medicine. 2011; 9(1): 29. PMid: 21418664. https://doi.org/10.1186/ 1479-5876-9-29

[64] Dragoo JL, Lieberman JR, Lee RS, et al. Tissue-engineered bone from BMP-2-transduced stem cells derived from human fat. Plastic \& Reconstructive Surgery. 2005; 115(6): 1665-1673. https : //doi.org/10.1097/01.PRS.0000161459.90856.AB

[65] Hoke NN, Salloum FN, Kass DA, et al. Preconditioning by Phosphodiesterase-5 Inhibition Improves Therapeutic Efficacy of Adipose-Derived Stem Cells Following Myocardial Infarction in Mice. Stem Cells. 2012; 30(2): 326-335. PMid: 22102597. https : //doi.org/10.1002/stem.789

[66] Patel KM, Crisostomo P, Lahm T, et al. Mesenchymal stem cells attenuate hypoxic pulmonary vasoconstriction by a paracrine mechanism. Journal of Surgical Research. 2007; 143(2): 281-285. PMid: 17868699. https://doi.org/10.1016/j.jss.2006.11.006

[67] Kowal J, Tkach M, Théry C. Biogenesis and secretion of exosomes. Current Opinion in Cell Biology. 2014; 29(1): 116. PMid: 24959705. https://doi.org/10.1016/j.ceb.2014.05.004

[68] Tetta C, Ghigo E, Silengo L, et al. Extracellular vesicles as an emerging mechanism of cell-to-cell communication. Endocrine. 2013; 44(1): 11-19. PMid: 23203002. https://doi.org/10.1007/ s12020-012-9839-0

[69] Rani S, Ryan AE, Griffin MD, et al. Mesenchymal Stem Cellderived Extracellular Vesicles: Toward Cell-free Therapeutic Applications. Molecular Therapy. 2015; 23(5): 812. PMid: 25868399. https : //doi .org/10.1038/mt.2015.44

[70] Arslan F, Lai RC, Smeets MB, et al. Mesenchymal stem cell-derived exosomes increase ATP levels, decrease oxidative stress and activate PI3K/Akt pathway to enhance myocardial viability and prevent adverse remodeling after myocardial ischemia/reperfusion injury. Stem Cell Research. 2013; 10(3): 301-312. PMid: 23399448. https://doi.org/10.1016/j.scr.2013.01.002 